\title{
$\mathbb{Z}$ Muke $\mathfrak{Z}$ aw $\mathfrak{J}$ ournal
}

\section{THE REVISED MODEL STATE ADMINISTRATIVE PROCEDURE ACT-REFORM OR RETROGRESSION?}

\author{
Harold S. BloomenthaL*
}

\section{INTRODUGTION}

7 HE ADMINISTRATIVE process during the past ten years has provoked anew discussion and reform proposals. Dissatisfaction with the status quo in administrative procedures is reflected in the approval by the National Conference of Commissioners on Uniform State Laws in late 1961 of a substantially revised ${ }^{1}$ Model State Administrative Procedure Act (hereinafter sometimes referred to as the Act or Model Act), which prior to revision was initially considered in 1944 and adopted in 1946.2 Substantial portions of the Model Act had been adopted as of the close of 1962 in seven states and the revised Model Act had been adopted in one state. ${ }^{3}$

Current interest in the reform of administrative law on both a federal and state level can trace itself back to the Task Force Report

- B.S. 1942, Marshall College; LL.B. 1947, Duke University; J.S.D. 1950, Yale University. Professor of Law, University of Wyoming; Visiting Professor of Law, Duke University, 1963.

' HaNDBOOK OF THE NAT'L CONFERENCE OF COMM'RS ON UNIFORM STATE LAWS 206 (1961). Hereinafter references to the revised Model Act and the official comments thereto will be by section number only.

3 HaNdBook of the Na't'L Conference of Comm'rs on UnIform State Laws 202 (1946).

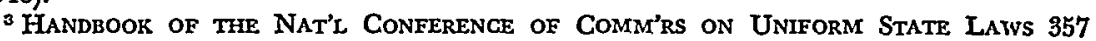
(1962). Although the Commissioners on Uniform State Laws only claimed eight states (Hawaii, Maryland, Michigan, Missouri, Oregon, Washington and Wisconsin) for the Model Act and Rhode Island for the revised Model Act at the end of 1962, other states have undoubtedly been influenced by the Model Act, and one study lists sixteen states as having adopted significant portions of the Model Act. KeNTuCkY Legislative Research Comm'n, Administrative Procedures Law in Kentucky (1962). Dean Stason tabulates four states as adopting the Model Act substantially verbatim and eight additional states as having adopted substantial portions of the Model Act. Administrative Law News No. 3, Nov. 1961, p. 2, col. 1. 
on Legal Services and Procedures ${ }^{4}$ of the second Hoover Committee. This report has inspired proposals to drastically revise the Administrative Procedure Act ${ }^{5}$ (hereinafter referred to as the APA) on the federal level and the Model Act on the state level. Although not adopted completely, the Task Force recommendations are the basis for the current (but no longer so recent, since they were initially proposed in 1956) ${ }^{6}$ proposals (hereinafter referred to as the $\mathrm{ABA}$ proposals) of the American Bar Association Special Committee on Legal Services and Procedure. ${ }^{7}$

The ABA proposals include proposals (I) to establish an office of administrative procedure and legal services which would be within the executive branch but independent of any department or agency thereof, (2) to establish a corps of independent hearing commissioners, (3) to establish as part of the judiciary, specialized administrative courts to have jurisdiction over certain adjudicatory functions presently being performed by the Federal Trade Commission and the National Labor Relations Board, and (4) to adopt the Proposed Code of Federal Administrative Procedure, drastically revising and superseding the Administrative Procedure Act of 1946. Several of the proposed code provisions have found their way into the revised Model Act and are commented upon separately below. ${ }^{3}$

Those who read the newspapers may recall that in 1957 an administrative law professor left his ivory tower at New York University to become counsel to a special subcommittee of the House long enough to shake up the administrative process, particularly with respect to alleged influenced peddling, to such an extent that it soon became expedient for him to resign his position with the subcommittee. ${ }^{9}$ The subcommittee's investigations continued on a more subdued tone for a period of time.10 The Senate established its counterpart subcommittee (hereinafter referred to as the Carroll com-

\footnotetext{
- United States Comm'n on Organization of the Executive Branch of the Gov't (1953-1955), TAsK Force Report on Legal Services and Procedure (1955).

60 Stat. 239 (1946), 5 U.S.C. $\$ 1001$ (1958). The Administrative Procedure Act will hereinafter be cited as APA.

'See Report of the Special Comm. on Legal Services and Procedure, 81 A.B.A. REP. 491 (1956). The Code of Administrative Procedure, which is included among these proposals, is hereinafter cited as the Proposed Code of Administrative Procedure.

${ }^{2}$ For an excellent discussion of proposals to reform the administrative process in. cluding the American Bar Association proposals, see Woll, Administrative Law Reform: Proposals and Prospects, 41 NEB. L. REv. 687 (1962).

${ }^{8}$ See text of article at notes $36,45,63,66,70,74,77,85,87,89,94,100,126$ infra.

- Schwartz, The Professor and the Commissions (1959).

${ }^{10}$ Woll, supra note 7 , at 715 .
} 
mittee) under the chairmanship of former Senator John Carroll of Colorado.11 The Carroll committee conducted extensive hearings pertaining to the administrative process in general, considering among other matters the ABA proposals. ${ }^{12}$ The Carroll committee has made several recommendations, some of which are considered below. ${ }^{13}$ A subcommittee of the Judiciary Committee of the House is presently holding hearings on the ABA proposals and other aspects of the administrative process.

In September of 1960 Judge E. Barrett Prettyman of the Court of Appeals for the District of Columbia was requested by President Eisenhower to initiate the organization of a conference on administrative procedures. This program was implemented by President Kennedy, who established, by Executive Order No. 10934 of April 13, 1961, the Administrative Conference of the United States. The conference consisted of representatives from both inside and outside the administrative agencies, including lawyers, professors and others with a special interest in administrative procedures. This conference studied a number of administrative law areas and problems under the terms of the executive order which terminated in December of 1962. There have been legislative proposals to make the Administrative Conference a permanent one. At least three important recommendations have come out of this conference; these recommendations are discussed below ${ }^{14}$ in the context of the problems to which they relate.

Immediately after President Kennedy was elected, he designated James Landis, former Dean of Harvard Law School and former Chairman of the Securities and Exchange Commission, to prepare a special report on the regulatory agencies. ${ }^{15}$ Some of the Landis recommendations were reflected in reorganization plans for certain agencies submitted by the President and adopted by Congress with modification as discussed below. ${ }^{16}$

In view of the foregoing, it is apparent that at least much talk

${ }^{11}$ Ibid. The present chairman of this subcommittee is Senator Edward V. Long of Missouri.

${ }_{12}$ Subcommittee on Administrative Practice and Procedure of the Senate Comm. on the Judiciary, Administrative Practice and Procedure, S. REP. No. 168, 87th Cong., Ist Sess. (1961).

${ }^{13}$ See text of article at notes $20,28,46,82,96,132$ infra.

14 See text of article at notes $46,55,82,118$ infra.

${ }^{16}$ Landis, Report on Regulatory Agencies to the President-Elect (Dec. 1960); reprinted by the Subcommittee on Administrative Practice and Procedure of the Senate Comm. on the Judiciary, 86th Cong., 2d Sess. (Comm. Print 1960).

${ }^{10}$ See text of article at note 47 infra. 
is going on in this area; how productive or constructive it is may be another matter. One critic of the administrative law writers has characterized much of the repetitive discussion as "an exercise in pouring old beer into new steins-producing a stale, flat potion."17 It is with some temerity that the author runs these same risks, but such risks cannot be avoided since the revised Model Act is based on these same repetitive discussions.

The Model Act, as revised, concerns itself with administrative adjudication $^{18}$ (referred to as "contested cases" and defined to include rate-making and licensing), rule making, and judicial review of administrative adjudication and rule making. In the area of rule making, the Act prescribes procedures for the adoption and publication of rules and for judicial review of rules to determine their validity. In the area of administrative adjudication, the Act prescribes the right to a hearing, the "pleadings," the right to present evidence and to cross-examine, rules of evidence, and the form, manner of reaching, and bases for the agency decision. The Act provides for judicial review of agency decisions in contested cases, and prescribes the procedure, mechanics and record on review, and the scope of judicial review. The Act also contains certain provisions limited in application to licensing.

II

\section{Goals and ObJectives}

Before exploring the Act in detail, it may be well to outline objectives and goals. In this emotionally charged area, all too frequently personal prejudices pass for informed judgment largely

The recommendation of the Conference and the selected studies of the Conference have been recently published as S. Doc. No. 24, 88th Cong., 2d Sess. (1963). S. 1664, 88th Cong., 2d Sess. (1963), which provides for a permanent Administrative Conference of the United States, recently was the subject of a Senate hearing. Hearing on S. 1664 Before the Subcommitte on Administrative Practice and Procedure of the Senate Committee on the Judiciary, 88th Cong., 2d Sess. (1963).

${ }_{17}$ Massel, The Regulatory Process, 26 LAw \& Contemp. Prob. 181 (1961).

${ }_{18}$ Thróughout the text reference is made to administrative adjudication in order to refer to the area labelled "contested case" by the revised Model Act. The term "adjudication," preferred as it is more descriptive, is the term usually employed on the federal level, and "contested case" will suggest to many a contest as distinguished from a consent or default proceeding. It should be noted, however, that "contested case" under the revised Model Act $(\$ 112)$ is broader than "adjudication" under the APA since it encompasses certain rate and other proceedings which are not "adjudi. cation" under the APA, but which under the APA are subject to some of the same hearing requirements. The term "adjudication" as used herein is used in the brotd sense to cover all proceedings involving a hearing on the record and which on the federal level would be subject to the hearing requirements of APA $\$ \$ 7-8$. 
because goals have not been clarified. The author believes that there would be substantial agreement on the following goals:

1. The goal of a model act in this area should be to improve and not to destroy, harass or hamper the administrative process. This requires recognition of the fact that administrative agencies are here to stay. It also requires consideration of administrative law problems without regard to the substantive rights that are affected by administrative action. All too often the alleged objections to administrative practices are a mere camouflage for substantive objections to the laws that are being administered. The substantive battles are to be fought in the legislature, and, assuming that the legislature has resolved the substantive problems in terms of a particular program, the concern should be with the fairness and efficiency of the procedures used in order to implement the substantive program. ${ }^{19}$

2. Another goal is recognition of the fact that the administrative process has its own character and values and is in itself a method (and the one preferred by the legislature) of handling a particular problem. Judicial methods should be adapted only to the extent they have worked well for the judiciary and will work well in the context of the particular problem. ${ }^{20}$ Trial-type adversary proceedings characteristic of most judicial proceedings are primarily useful for determining adjudicative facts and should not be imposed on proceedings that essentially involve questions of policy determination.

3. The goal in the area of administrative adjudication should be to provide a minimum in the way of fair hearing procedures without judicializing the administrative process. Assuming the appropriateness of a trial-type hearing, administrative due process should include (without undue formality) adequate notice of the issues, adequate

${ }^{10}$ This does not suggest that one need not be concerned with the impact of administrative procedures on an agency's ability to accomplish its substantive functions. See Massel, supra note 17, at 181-82.

${ }^{20}$ The report of the Carroll committee states this well: "Agencies and departments have been bedeviled by an insistence that their procedures resemble as closely as possible court techniques. Too little emphasis has been placed upon the fact that administrative determinations involve the interests of many ... parties; that the facts to be determined depend not upon resolving conflicts between witnesses as to who did what, and when, and to whom, but upon predictions of the future based upon evaluation of statistical and scientific data. Most of all, the issue is often not low to resolve a conflict between adversaries, but to determine what the public interest demands shall be made to happen in the future. The unavoidable result of forcing such a "decision to be made in a proceeding contorted into a judicial mold is a long and complicated but often inadequate record ...." Subcommittee on Administrative Practice and Procedure of the Senate Comm. on the Judiciary, supra note 12, at 2. 
opportunity to prepare, adequate opportunity to discover and present evidence, and the right to cross-examine and confront opposing witnesses. Persons affected by administrative action are, in short, entitled to their day in the administrative court.

4. The agency decision in administrative adjudication should be rendered by unbiased persons ${ }^{21}$ who have personally considered the record, have not been contaminated by participating in the prosecution of the case, and who have rationalized their decision in a written opinion setting forth the basis for their conclusions.

5. Each agency should have rules of practice governing the agency's procedures in administrative adjudication. These rules of practice, as other rules, should be readily available to all parties.

6. Procedures for the promulgation of rules and regulations by agencies should assure participation by persons affected by such rules and regulations and should assure publication, indexing and codification of the rules and regulations.

7. Reform of administrative law should have due regard for the peculiar advantages of the administrative process growing out of the special competence of the administrators in their area of jurisdiction and growing out of the institutional approach to such problems. One of the principal advantages of the administrative agency is the fact that the agency head does not have to depend on his own limited knowledge but has available to him a staff of trained personnel that can bring a more specialized and studied approach to the problems with which the agency must deal. Of the goals listed, this perhaps will be the most controversial since it infringes on some persons' ideal of separation of functions. ${ }^{22}$

\section{III}

\section{Survey of the Model Act's Contributions}

The Model Act and its recent revision can, if carefully considered, become the basis for administrative law reform in states

\footnotetext{
${ }^{21}$ This does not, of course, require neutral agency members; obviously, members of the agency should be sympathetic with the objectives of the legislation, and they are not precluded from prejudgments as to what constitute the desideratum of law and policy. United States v. Morgan, 313 U.S. 409 (1941). Some courts are all too prone to assume that administrative due process cannot adequately protect parties. See, e.g., the assumption of the Tenth Circuit to the effect that administrative procedures within the Dep't of Interior for resolving issues under the Mineral Leasing Act may destroy the security of titles to oil and gas leases. Pan American Petroleum Corp. v. Pierson, 284 F.2d 649, 655 (10th Cir. 1960).

${ }^{22}$ See text of article at notes $69-91$ infra.
} 
either without legislation in this area or with antiquated or inadequate legislation. The revised Model Act makes a significant contribution in the following areas:

1. In the area of administrative adjudication, many state administrative agencies have not adopted rules of practice governing the procedures to be followed in the administrative adjudication, and in other instances inadequate and incomplete rules of practice have been adopted. The Model Act remedies these deficiencies by first providing for minimum procedures governing all administrative adjudication and, in addition, requiring each agency to adopt rules of practice supplementing the procedures provided. In some state agencies, the Model Act will provide procedures and gnidance in areas for which no regular procedures or governing standards were previously available.

2. One of the major contributions of the Model Act and the revised Model Act is in the area of rule making. It provides a uniform procedure for the adoption of rules that assures notice to interested parties with an adequate opportunity to present conflicting viewpoints and with provision for filing, indexing, compiling, publishing, and keeping current the publication of rules.

3. In many instances decisions of state administrative agencies are rendered in administrative adjudications without setting forth specific findings of fact or conclusions of law or a sufficient rationalization for the decision, thereby making difficult the process of judicial review and creating the impression of arbitrary action. The Model Act as revised requires decisions in administrative adjudication to be in writing and to set forth the findings of facts and conclusions of law; the findings of fact must be set forth concisely and explicitly.

4. Administrative agencies on the state level have undoubtedly in many instances been deficient in failing to develop in administrative adjudication an appropriate record of the proceedings. The lack of such record creates problems with respect to judicial review and does not contribute to informed administrative decisions. The Model Act prescribes the content of the record, but as we shall see, it is deficient in failing to provide for adequate reporting of testimony and in failing to take into consideration related matters essential to the development of an appropriate record. ${ }^{23}$

\footnotetext{
${ }^{23}$ See text of article at notes $56-62,67$ infra.
} 
5. The Model Act contains judicial review provisions pertaining to rule making and administrative adjudication and, although, as noted below, ${ }^{24}$ it is somewhat inadequate in these respects it does take a long step forward toward eliminating unnecessary confusion in the selection of the appropriate form of proceeding for judicial review. The Model Act also prescribes certain standards for controlling scope of review which are discussed below.

\section{IV}

\section{Survey of The Revised Act's Shortcomings}

Some of the proponents ${ }^{25}$ of the Model Act have recognized that each state will have to tailor the Model Act to its own peculiar needs in the area of administrative law. A model act in conception is intended as a general guide rather than a prescription for uniformity. Certainly, administrative law problems differ in nature and degree from state to state, depending in part upon the size of the particular state, and from agency to agency depending somewhat upon the functions performed and the particular work load encountered. In addition, each state ordinarily has to consider constitutional limitations that may preclude or at least require modification of proposed changes in procedures, particularly with respect to judicial review.

Of crucial importance in reforming state administrative procedures is recognition of the fact that those concerned with the administrative process on a day-to-day basis must be made participants in proposals for reform. The revised Model Act does not reflect a drafting procedure that sought or seriously considered viewpoints of state administrators most vitally concerned with the impact of the proposed Act.2 ${ }^{2}$ Accordingly, states contemplating legislation in this area would be well advised to make representatives of the administrative agencies participants in the drafting process. This is not to suggest that the viewpoints of such administrative personnel must always be controlling, and there undoubtedly are

\footnotetext{
24 See text of article at note 115 infra.

2s This has been recognized by Raoul Berger, Chairman of the Administrative Law Section of the American Bar Association, among others. See The Administrative Law News No. 3, Nov. 1961, p. 1, col. 1. Mr. Berger, however, presumably would not agree with the major revisions suggested in this article.

20 The special committee on revisions of the Model Act included E. Blythe Stason, Chairman, John B. Boatwright, Jr. of Richmond, Virginia, James J. Burke of Madison, Wisconsin, and Charles Wheeler of Frankfort, Kentucky.
} 
areas in which the administrators need to be prodded $^{27}$ and their viewpoints disregarded if effective reform is to be achieved. However, these should be areas in which the need for reform has been established rather than proposals based on a doctrinaire approach ${ }^{28}$ without adequate empirical bases. Reform in the administrative process should not preclude the administrators from carrying out their responsibilities. The agency has the responsibility and the duty to enforce and administer vigorously and sympathetically the substantive law entrusted to it; the agency must have the tools necessary to cut through obstacles that represent primarily delaying tactics and retreating action on the part of the regulated. As we note below, ${ }^{29}$ the revised Model Act poses a number of such obstacles and it is inconceivable to this author that this most recent revision of the Act will achieve widespread acceptance on the part of those responsible for carrying out administrative programs unless it is substantially revised in certain material respects.

The proposed Model Act adopts many of the restrictive provisions recommended by the Task Force and included among the ABA proposals, but it completely disregards thinking and practices going on within agencies themselves and arising out of the recommendations of the Administrative Conference and others in areas such as ex parte consultation, delegation of decision and reviewing powers, and limitations on the review of decisions of hearing officers. In addition, in many respects the Model Act as revised fails to deal at all with a number of siguificant administrative law problems. Irrespective of particular viewpoints, since the Model Act necessarily reflects a compromise of many viewpoints, those intimately concerned with the drafting of legislation for a particular state should be familiar with the ferment of ideas so characteristic of the modern administrative law field. The author has participated in one program for drafting a state administrative procedure act ${ }^{30}$ and con-

\footnotetext{
${ }^{27}$ See particularly discussion in text of article at note 58 infra.

${ }^{28}$ Compare the following statement of the Carroll committee relating to the Proposed Code of Administrative Procedure: "The Committee is frank to observe that there is little in the way of concrete evidence pointing to any need for increased formalities." Subcommittee on Administrative Practice and Procedure of the Senate Comm. on the Judiciary, supra note 12 at 10.

${ }^{20}$ See discussion in text of article at notes 65-66 and notes 69-91 infra.

${ }^{30}$ See Bloomenthal, Administrative Law in Wyoming-An Introduction and Pre. liminary Report, 16 WYo. L.J. 191 (1962); CoMM. ON ADMINISTRATIVE LAW OF THE Wyoming Bar Ass'n, A Proposed Wyoming Administrative Procedure Act (Dec. 14, 1962). The author must report that these efforts have not been successful to date in part because of disagreement as to whether changes in judicial review procedures should be accomplished by legislation or by adoption of supreme court rules.
} 
cludes on the basis of this participation that it is possible to adapt the Model Act so as to serve as a basis for administrative reform. This conclusion is buttressed by studies being made in other states. ${ }^{31}$

\section{V}

\section{Coverage and Administration of an Administrative Procedure Act}

In large measures the Model Act as revised is self-executing and requires no more than compliance with its provisions by the agencies covered under the Act's definition of the term "agency." 32 This definition is all inclusive on the state level. However, the Model Act does not include municipal and county administrative agencies, although the official comment to the Act suggests that it may be desirable to add some of these. There are typically on the county and municipal level several agencies, such as zoning boards of adjustments and civil service commissions, which exercise significant powers of adjudication with a sufficient degree of regnlarity to warrant their inclusion within the coverage of a state administrative procedure act. In addition, administrative action by county and local agencies frequently gives rise to problems of judicial review and, if the judicial review provisions are expanded, as suggested below, to cover administrative action in addition to rule making and contested cases, ${ }^{33}$ the judicial review provisions should be extended to similar administrative action on the county and municipal level.

There are certain functions under the Model Act which have to be performed either by an existing agency or department or by a new agency. The principal function involved is the publication and compilation of rules and proposed rules. There are in addition, however, other functions that could be vested with profit in a particular agency or department. The approach of the Model Act is to vest centralized functions that have to be performed under the Act in the office of the secretary of state or in another agency to be designated by the legislature. The Kentucky proposed act ${ }^{34}$ places these functions in its legislative research commission. The author would suggest consideration be given by states revamping

\footnotetext{
${ }^{31}$ See, for example, Kentuckx Legislative Research Comm'n, supra note 3.

32 Revised Model Act $\$ 1$ (1).

${ }^{33}$ See text of article at note 108 infra.

3 ' Kentucky Lfoislative Research Comm's, supra note 3, at 57.
} 
their administrative procedures to the creation of a separate agency (hereinafter referred to as the Administrative Procedures Commission) as part of the executive department which would have, among others, the following functions:

1. To compile and publish rules and proposed rules, as required under the Model Act. ${ }^{35}$

2. To gather statistics and other data relating to administrative procedures and designed to lead to proposals or suggestions to improve the efficiency of the administrative process.

3. To make studies for structural reorganization upon the request of a particular agency.

4. To advise particular agencies, upon their request, regarding the handling of problems relating to administrative procedures and law.

5. To control the selection, promotion, assignment, and general supervision of hearing examiners.

On the federal level there is presently an Office of Administrative Procedure within the United States Department of Justice. This office performs some of the functions mentioned above, but it does not have control over hearing examiners. The American Bar Association has proposed that the Office of Administrative Procedure or a comparable office be made an independent agency in the executive branch of the federal government, and the functions proposed to be vested in this agency include control over the selection and supervision of hearing examiners. ${ }^{36}$ The draftsmen of administrative procedures legislation may want to review other functions which the $A B A$ proposes to vest in the Office of Administrative Procedure with the possible view of including some of these additional functions in the proposed Administrative Procedures Commission.

VI

Administrative Adjudication Under the Model Act

\section{A. Rules of Practice}

The first requirement for administrative adjudication is that the agency have established procedures for conducting such adjudication, embodied in the form of rules of practice that are available to

\footnotetext{
${ }^{35}$ Revised Model Act $\$ \S 4,5$.

so Proposed Code of Administrative Procedure, S. 600, 86th Cong., 1st Sess. \$§ 204-11 (1959).
} 
all persons affected by such adjudication. The Model Act in itself supplies a skeleton set of rules; the detail relating to implementation, however, is quite properly left to the individual agencies. The Model Act also affirmatively requires that each agency adopt rules of practice.37 Most state agencies with substantial case loads undoubtedly have the personnel and facilities necessary in order to adopt rules without outside assistance. However, many of the smaller agencies may have inadequate staffs for this purpose, and there is merit in the Oregon act $^{38}$ which provides that the attorney general shall be required, upon request, to submit to the requesting agency a proposed set of rules of practice to be considered for adoption by the agency.

\section{B. Presiding Officers}

The Model Act is seriously deficient in that, although it assumes that hearing officers may be appointed and apparently assumes that the decision making power may be delegated, it makes no provision for hearing officers and does not specify generally the powers to be exercised by presiding officers, the weight to be afforded decisions of the presiding officers, and the procedures for review of decisions of presiding officers. These are matters which for the most part are explicitly covered by the APA and involve areas of intense current discussion, with many proposals being debated and with considerable experimentation being undertaken by some of the federal administrative agencies. These problems on the state level have their own peculiar character arising out of, among other things, the fact that in many of the smaller licensing agencies, the members of the agency have had no significant experience in presiding as "judicial" officers; in many other agencies by virtue of constitutional or statutory provisions ex officio members of the agency, such as the governor and secretary of state, have to participate in the decision making process. These additional factors give impetus to the need arising in all agencies with a large case load of administrative adjudication or in agencies in which the members have substantial and significant additional functions to perform to have trained persons other than the members of the agency, or perhaps only one member of the agency, to preside at and conduct the administrative hearing. A major consequence of employing the hearing examiner procedure

${ }^{37}$ Revised Model Act \$2 (a) (2).

${ }^{38}$ Ore. Rev. STAT. $\$ 183.340$ (1959). 
is that final decisions frequently are rendered based on a review of the record by persons other than those who have actually heard the testimony.

No one on the federal level disputes the need for hearing examiners or other procedures that permit someone other than the complete agency membership to preside at hearings, but considerable controversy rages as to (1) the qualifications, appointment, salaries, and supervision of hearing examiners, (2) the extent to which decisions of the hearing examiners or other presiding officers should be binding upon the agency, and (3) the extent to which parties should be entitled as a matter of right to an appeal to the agency from such decisions. The Model Act is mute on all these matters.

There are undoubtedly a large number of state agencies which have statutory authority to employ hearing officers and which have well developed practices in this area. The Colorado act ${ }^{39}$ and Kentucky proposed act ${ }^{40}$ both authorize the use of hearing examiners, but they do not specify their qualifications or the manner of their appointment. As a minimum, a proposed state administrative procedure act should contain comparable provisions. The merit of this approach is its flexibility in that it apparently permits any designated employee to preside. Other and more preferable alternatives would include the federal approach, which provides for a special class of hearing examiners who are employees of the individual agencies but somewhat insulated from agency influence, ${ }^{41}$ or the creation of a separate class of hearing examiners who would be employed, supervised, and assigned to cases by the Administrative Procedures Commission. ${ }^{42}$

The weight to be afforded decisions of hearing examiners and the extent to which parties are entitled to review are necessarily intertwined. Under the APA, with respect to matters resolved by a trial type hearing, the decisions of the hearing examiners are subject to review as a matter of right and are not binding upon the .agency. ${ }^{43}$ However, with respect to matters involving credibility of

\footnotetext{
${ }^{30}$ Colo. Rev. Stat. \$ 3-16-4 (3) (1960 Perm. Supp.).

${ }^{\circ}$ Kentucky Legislative Research Comm's, supra note 3 , at 68.

1 APA $\S \S 7,11$. See Ramspeck v. Federal Trial Examiners Conference, 345 U.S. 128 (1953). In such event provision should be made to permit the smaller agencies to borrow hearing examiners from other ageucies as needed.

4 This follows one of the ABA proposals. See supra note 36 .

4 Depending upon classification of the case and the particular rule of practice adopted by the agency, the examiner's decision is an initial decision or a recommended decision, but in any event parties have the right to review by the agency. APA $\$ 8$ (a).
} 
witnesses, the reviewing court must consider the fact that the hearing examiner reached the same or different (as may be appropriate) conclusion in determining whether the findings of fact of the agency are supported by substantial evidence. ${ }^{44}$ Under the ABA proposal, hearing examiners' decisions are final unless reviewed, and the agency cannot set aside findings of evidentiary facts (as distinguished from ultimate conclusions of fact and questions of agency policy) unless contrary to the weight of the evidence. ${ }^{45} \mathrm{~A}$ bill introduced by Senator Carroll goes even further by authorizing review of the hearing examiners' decision only if (1) a finding of fact is clearly erroneous; (2) there is no governing legal precedent; (3) the decision departs from governing laws, rules and precedent; (4) a substantial and important question of administrative policy or discretion has been raised; or (5) prejudicial procedural error has been committed. ${ }^{46}$ Under various reorganization acts pertaining to certain regulatory agencies (based in part on the Landis recommendations), the agency has discretion of the certiorari type to review; ${ }^{47}$ review can be by employees or employee boards; $\mathbf{4 8}^{48}$ and in some instances review exists as a matter of right, but it can be by employees

\footnotetext{
« Universal Camera Corp. v. NLRB, 340 U.S. 474, 493-94 (1951).

45 Proposed Code of Federal Administrative Procedure $\$ 1007$ (c). For a discussion of this and other provisions of the Proposed Code written by one of its proponents see Benjamin, A Lawyer's View of Administrative Procedure-The American Bar Association Program, 26 LAw \& ConteMP. ProB. 203 (1961).

${ }^{6} \mathrm{~S}$. 1734, 87th Cong., 1st Sess. $\$ 8$ (a) (1961). The Administrative Conference of the United States at its third plenary session held on April 3, 1962, adopted recommendations in support of a revised S. 1734. However, as revised, the agency would retain discretion as to whether or not to grant review, and the statutory grounds listed in the text would be controlling only as to a party's right to review.

${ }^{17}$ See Schultz, Progress and Problems in Agency Adjudication, 14 AD. L. Rev. 289 (1962), for an excellent discussion of legislation, reorganization plans, implementing rules and general background. Reorganization Plan No. 3 of 1961 (5 U.S.C.A. \$ 133z-15 Supp. 1951-61) and Reorganization Plan No. 4 of 1961 (ibid.) permit the Civil Aeronautics Board and the Federal Trade Commission respectively to delegate the power to "determine" with discretionary review (but any two members of the board, that is one less than a majority, may require agency review). Legislation adopted in 1962 permits similar delegations to be made by the Securities and Exchange Commission; however, as to certain types of commission action, review exists as a matter of right and in all instances one member of the commission may require review. P.L. 87-592, 76 Stat. 394 (1962). The Atomic Energy Commission by regulation has adopted a discretionary review procedure. 10 C.F.R. $\$ 350$ (1959). The Federal Trade Commission has exercised its authority to limit review in accordance with the foregoing; both the Securities and Exchange Commission and the Civil Aeronautics Board continue to aliow review as a matter of right.

"8 The Interstate Commerce Commission procedures now utilize "appellate" em. ployee review boards on a large scale. Authorization for such boards is contained in $\$ 17$ (b) of the Interstate Commerce Act as amended in 1961. 75 Stat. 517 (1961), 49 U.S.C.A. $\$ 17$ (b) (1961).
} 
or employee boards. ${ }^{49}$ A recent study by the ABA Committee on Agency Adjudication tentatively concluded that many of the a priori concerns as to shortcomings of employee review boards have not materialized in practice. ${ }^{50}$ Somewhat belatedly there has been recognition not only of the fact that S. 1734 would place an agency in a straight jacket review-wise and contribute to the judicialization of the administrative process, but it would also eliminate one of the most important safeguards against administrative authoritarianism, to wit, various levels of review as a matter of right. ${ }^{51}$ The use of employee boards to reduce the work load of the agency, thereby allowing it to concentrate on the more important cases, should permit agencies to reduce the backlog of cases $^{52}$ without denying parties the right to another level of review. Serious consideration should be given in a proposed state act to providing for agency review as a matter of right, retaining the advisory status of the hearing examiner's decision but making his decision final unless appealed or reviewed by the agency on its own motion, and permitting the agency to delegate its review functions as it may determine to an employee or an employee board. ${ }^{53}$

The Model Act makes no provision as to the functions and powers of the presiding officer. The provisions of the APA ${ }^{54}$ which relate to administering oaths, rules upon offers of proof, etc., could serve as the basis for a comparable provision on the state level. Consideration should also be given to areas in which pre-hearing conferences might be better utilized in administrative adjudication. ${ }^{55}$

\footnotetext{
${ }^{60}$ The Federal Communications Act, as amended in 1961, with respect to most adjudicatory proceedings permits review as a matter of right, but review may be performed by employee boards which in the case of adjudication, as defined by the APA, must be a three member board, the members of which meet certain statutory standards. 75 Stat. 420 (1961), 47 U.S.C.A. $\$ 155$ (d) (1961). There is a further limited right to petition to the agency for review of the decision of the employee board with discretionary right in the agency to deny further review. All of the statutes referred to in notes $47-49$ preserve the requirement that proceedings subject to $\$ 7$ (a) of the APA can be presided over and conducted by either the agency, one of its members, or a qualified hearing examiner.

${ }^{50}$ Schultz, supra note 47 , at 258.

E1 Id. at 258-59.

$\checkmark 2$ Ibid.

${ }^{53}$ The amendment to the Federal Communications Act referred to at note 49 supra could well serve as a model.

st APA $\$ 7(\mathrm{~b})$. The Model Act also fails to assure parties right to counsel. Compare APA $\$ 6$ (a) with a bill introduced in tbe 88th Cong., lst Sess. by Senator Edward V. Long. Press Release from office of Senator Edward V. Long dated May 8, 1963.

os The Administrative Conference has recommended (Recommendation No. 19) utilization in some cases of documentary presentation of cases by the parties prior to hearing so as to limit the hearing to cross-examination. Subject to the rules of evi-
} 


\section{Investigations and Discovery}

The regulatory administrative agency has dramatized the need for, and the results that can be accomplished with, the subpoena power used as an implement for conducting investigations. The subpoena is also utilized to obtain essential data relating to the adopting of rules and legislation as well as in connection with the regulatory type adjudication. In addition, it is essential to an appropriate record that the subpoena power be available to all the parties to an administrative adjudication and not merely to the agency and its staff.

Since most agency statutes on the state level provide for the subpoena power, the more serious problems are (l) making the subpoena power available to the parties other than the agency, and (2) providing for pre-hearing discovery. The Model Act contains no provisions pertaining to issuing subpoenas, making the subpoena power available to parties, or directly providing for discovery. Discovery by parties other than the agencies, in fact, is a largely neglected area of administrative law on both the state and federal level. Since the administrative agencies have powerful discovery weapons available to them, a staff of trained investigators to effectively use such weapons, and generally the time and money to investigate thoroughly, the administrative adjudication involving the agency against the individual is decidedly one-sided from the standpoint of discovery techniques.

Discovery is one area in which the administrators definitely need prodding. Procedures for discovery against the agency as a matter of right and without the approval of the agency seldom exist. In some instances even the very limited discovery procedures available in criminal actions ${ }^{56}$ have been held to be unavailable to respondents in administrative adjudication. Although administrative agencies have begrudgingly, if at all, extended discovery procedures to other participants to the proceedings, the agencies have been expanding their power to investigate and now have, as is only appropriate, extremely powerful investigatory tools. ${ }^{57}$ Administrative adjudica-

dence (see text of article at note 65 infra) the revised Model Act $\$ 10$ permits evidence to be received in written form if the "hearing will be expedited and the interests of the parties will not be prejudiced substantially."

${ }^{6 B}$ See Great Atlantic \& Pacific Tea Co., 118 N.L.R.B. 1280 (1957). But see Communist Party v. Subversive Activities Control Board, 254 F.2d 314, 328 (D.C. Cir. 1958).

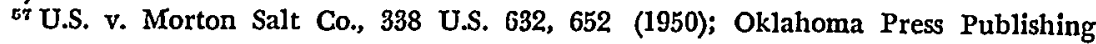


tion of the type involving litigation between two or more private parties would also be facilitated by discovery procedures comparable to those now generally provided under modern rules of procedure in civil actions. ${ }^{58}$

Consideration should be given in drafting a proposed administrative procedure act to extending the subpoena power to all administrative adjudications, to providing for issuance of the subpoenas by the agency or presiding officer upon request of any party, and to providing for a uniform enforcement procedure. Enforcement of the subpoena should require a court proceeding, and the Kentucky proposed act provision, ${ }^{59}$ designating the court of a particular judicial district to hear all subpoena enforcement cases, warrants consideration. The proposed statute should make clear, as does the Kentucky proposed act, that the enforcement proceeding may be initiated by any party. ${ }^{60}$

Rules of some state agencies provide for the taking of depositions, but these provisions frequently require the consent of the agency and often appear to pertain only to the taking of testimony as distinguished from discovery. The Kentucky proposed act ${ }^{61}$ would require that the notice in a contested case include notice of (and an opportunity to examine) all relevant staff memoranda and data which are not made confidential or privileged by statute. This provision undoubtedly will be criticized as making available the product of the agency's work to the other parties and thereby destroying the element of surprise, thus making it more difficult for the agency to win its cases. Since agencies are manned by human beings, to the extent they are participants in contested cases, those responsible for preparing the agency's case usually like to win. The function of agencies, however, is not to win cases merely for the sake of winning, and in the last analysis, the administrative process will gain more respect and be stronger if it does make its work product available within the limitations relating to confidential and privileged information. An alternative approach, broader and preferable in the sense that it permits discovery against the agency and other parties to the proceeding, would be to provide that rules comparable to those

Co. v. Walling, 327 U.S. 186 (1946); Endicott Jolınson Corp. v. Perkins, 317 U.S. 501 (1943).

${ }^{88}$ FED. R. Crv. P. 26-37, 45 (d), and comparable state rules of civil procedure can be adapted for this purpose.

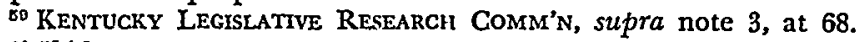

${ }^{80}$ Ibid.

as Ibid. 
in the Federal Rules of Civil Procedure be applicable to all administrative adjudication. The Federal Rules would require some minor adaptations in order to apply to administrative adjudication, and such modification should make clear the fact that, to the extent the agency is an adversary party, it shall be deemed a party for discovery purposes. The extent to which the agency's files and staff are protected as confidential or privileged should be left for determination by the courts on an ad hoc basis. ${ }^{62}$

D. Evidence, Official Notice, the Record and Findings

The exclusionary rules of evidence have not generally been applied in administrative proceedings on the state level. However, the "residium rule" adopted in some states does require that decisions be supported by a residium of competent evidence. ${ }^{63}$ Section 10 of the Model Act, revised following the ABA proposals, would require the rules of evidence as applied in non-jury civil cases to be applied in adjudication, with a proviso that when facts are not otherwise provable, evidence may be admitted in contravention of these rules if it is the type of evidence commonly relied upon by reasonably prudent men in the conduct of their affairs. The approach of the federal APA seems preferable to the author since it admits all relevant evidence which is not repetitious and merely requires that the decision be based on reliable, probative and substantial evidence. Reliable, probative and substantial evidence should be defined as the type of evidence commonly relied upon by reasonably prudent men in the conduct of their serious affairs.

The exclusionary rules of evidence were designed to protect litigants against juries which of necessity have limited experience in evaluating evidence. Most authorities on the law of evidence feel that many exclusionary rules need drastic revision, ${ }^{64}$ and there is no general agreement as to what the non-jury rules are or that they even exist. ${ }^{65}$ The revised Model Act provision seems tailored to produce interminable objections and argument as to what are the non-jury rules of evidence and other extraneous matters (e.g., is a fact otherwise provable) rather than concentrating on the relevancy,

${ }^{\circ 2}$ See Davis, Administrative LAw $\$ 8.15$ (1958), for compilation of the case law relating to such privilege.

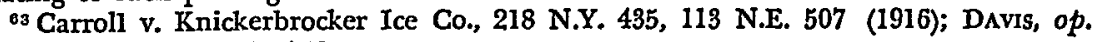
cit. supra note 62 , at $\$ 14.12$.

ot Id. $\$ 14.10$.

es Id. $\$ 14.04$. The revised Model Act $\$ 10(1)$ also appropriately requires agencies to give effect to the rules of privilege recognized by law. 
reliability and weight of the evidence. Any statutory enactment in this area should also put to rest the residium rule with respect to administrative adjudications.

The revised Model Act ${ }^{66}$ restricts official notice to generally recognized technical or scientific facts within the agency's specialized knowledge. A preferable provision in the author's judgment would be to permit official notice of any fact within the agency's files or records or specialized knowledge, provided the parties are afforded an opportunity to contest the facts so noticed. The agency should not be precluded from utilizing the storehouse of information it has accumulated in its files or otherwise. The revised Model Act appropriately requires notice of, and an opportunity to rebut, evidence officially noticed and apparently contemplates that such notice and opportunity to rebut will be afforded prior to the final decision; however, by the inclusion of an "or otherwise" proviso, agencies apparently could give such notice in the decision itself, and this proviso should be excluded.

The record developed in administrative adjudication is extremely important, for it ordinarily determines the basis for the decision and controls in part the nature and extent of judicial review. In the event all the members of the agency have not heard the case, it is essential that the proceedings be reported both for purposes of judicial review and in order to permit the entire agency to participate in the decision. A substantial number of the better staffed state agencies undoubtedly report proceedings as a matter of course. The Model Act, ${ }^{67}$ although it provides that the record shall include "evidence received or considered," does not, unfortunately, expressly provide that all contested cases be reported. The Model Act provision relating to transcription of the record should be enlarged so as to require that such transcription be furnished upon request of any party and upon payment of reasonable costs established by the agency.

Objection may be made to the reporting requirement because of the costs involved. The suggested provision, it should be noted, would merely require that the proceedings be reported rather than stenographically recorded, as the Kentucky proposed act requires. The purpose is to permit magnetic tape or other machine recording, and hence the cost would not exceed the cost of purchasing or

\footnotetext{
oo Revised Model Act $\$ 10$ (4).
}

${ }^{\circ}$ Id. $\$ 9$ (e) (2). 
leasing such a machine and accessories. While stenographic reporting is undoubtedly preferable and will undoubtedly continue to be used by agencies with available personnel, the recommended provision will at least assure some semblance of a record in all contested cases. It should also be noted that the suggested provision is limited to administrative adjudication; other requirements are more appropriate to rule making and to executive action. Executive action is usually reflected by minutes relating to the proceeding, and it does not appear appropriate to legislate requirements in this area.

Section 12 of the revised Model Act requires that any final decision in a contested case shall set forth findings of fact and conclusions of law, separately stated. Findings of fact, if set forth in statutory language, must be accompanied by a concise and explicit statement of the underlying facts supporting the findings. These provisions should not only help dispel impressions of arbitrary action, but in some instances at least they should also limit such action and facilitate judicial review. The revised Model Act also provides that if proposed findings of fact are submitted by the parties in accordance with the agency's rules, the decision must include a ruling upon each proposed finding. This provision, in the author's judgment, serves no useful function and will result in cluttering written opinions with extraneous material and meaningless "boiler plate." Section 12 of the Model Act also requires that notice of the final decision in contested cases be given to the parties and that a copy be mailed to each party requesting same. Further provision should be made requiring that each agency maintain an appropriately indexed public file of all its decisions in contested cases and that they publish, as required by the Kentucky proposed act, a summary of all such decisions in a monthly bulletin distributed in connection with the publication of proposed rules. ${ }^{68}$

\section{E. The Institutional Decision}

The institutional decision grows out of the needs and characteristics of the administrative process, and since the procedures differ from judicial procedures, there are continual efforts by lawyers to compel conformity to the judicial model. This explains in part proposals already discussed to make each hearing examiner in effect a trial court judge and to impose the non-jury exclusionary rules of

\footnotetext{
${ }^{68}$ Kentucky Legislative Research Comm'n, supra note 3, at 85. See also text of article at note 99 infra.
} 
evidence. ${ }^{68}$ Although some advocates of the ABA proposals prefer avoiding terms like "judicialize," "7o the Task Force of the Hoover Committee candidly recognized "formalization of administrative procedures along judicial lines"71 as their primary objective. The area which particularly disturbs the "judicializers" is the administrative decision making process, and it is in this area that the revised Model Act attempts to do something about it. There are many related aspects of the problem, and it may be well to attempt to outline them before proceeding to a detailed discussion.

First, there is the problem as to what constitutes the record upon which decisions in administrative adjudication are to be based and the extent to which the record must be read or considered by the agency itself. There is also the problem-related to the foregoing only because the revised Model Act chooses to make them relatedof the extent to which parties are to have the right to present briefs and to make oral argument.

Second, there is the problem of the extent to which the agency members may be assisted by the staff in sifting, analyzing, and evaluating the record and in preparing the written opinion.

Third, there is a problem of the extent to which parties and their representatives may confer ex parte with agency personnel who participate in the decision making process.

Fourth, there is a problem as to the extent to which members of the agency may consult with their staff in reaching decisions.

Fifth, there is a problem of separation of functions, cutting across all of the foregoing problems, involving the extent to which those who have participated in the investigation, preparation or presentation of the case on behalf of the staff may participate in the decision making process.

Let us consider the problems seriatim, reserving separation of functions for individual treatment.

(1) The revised Model Act requires that "findings of fact shall be based exclusively on the evidence and matters officially noticed."72 If the reference is to adjudicative or evidentiary facts as distinguished from ultimate conclusions of fact and legislative facts pertaining to policy, no one is likely to quarrel with this provision. The deter-

\footnotetext{
60 See text of article at notes 51,65 supra.

70 Benjamin, supra note 45 , at 212.

71 United States Comm'n on Organization of the Executive Branch of the Gov't, supra note 4, at 138 .

$7^{2}$ Revised Model Act $\$ 9(\mathrm{~g})$.
} 
mination, for example, that certain pricing practices have been engaged in is susceptible of record proof; the impact of these prices on competitors may or may not be, and whether such pricing practices are desirable probably can never be determined on the basis of evidence alone. The Model Act does not require that the agency members read the record; however, in an effort to require the agency members to master the record, the revised Model Act requires, in the event less than a majority of the agency participating in the decision have read the record or heard the case, that a proposed decision be prepared by a person who conducted the hearing or who has read the record. ${ }^{73}$ The proposed decision must be served upon the parties who then are to be afforded an opportunity to file exceptions and present briefs and oral arguments. ${ }^{74}$ All of this is justified in order to assure that those who decide have "at the very least" received briefs and heard oral argument. ${ }^{75}$ Ironically, under the Model Act the parties have no assurance of an opportunity to present briefs as a matter of right in the event a majority have read the record.

Certainly a modification of the APA procedure ${ }^{76}$ relating to the rendering of agency decision is preferable to the proposed revised Model Act procedure:

(a) A recommended decision by the presiding officer (ordinarily the hearing examiner) which will become the final decision of the agency unless appealed from or reviewed by the agency on its own motion.

(b) Parties as a matter of right to be afforded an opportunity to submit exceptions to the recommended decision supported by briefs. The brief is counsel's most effective opportunity to organize and effectively present his argument, and this opportunity should not be denied under any circumstances.

(c) Oral argument at the discretion of the agency.

(2) Under the revised Model Act, agency members or others who render decisions in contested cases as to an "issue of fact" can consult ex parte only other members of the agency or one or more personal assistants. ${ }^{77}$ This provision appears, among other things,

${ }^{73}$ Id. \$11.

74 Ibid.

${ }^{75}$ Comment $\S 11$, revised Model Act.

${ }^{78}$ The APA provisions are found at $\S 8$ (b) of that act.

${ }^{77}$ Revised Model Act $\S 13$. However, consultation is permitted by $\S 13$ to the extent necessary for the agency to dispose of ex parte matters authorized by law and presumably this will permit consultation for the purpose, for example, of determining whether or not a proceeding should be initiated. 
to be designed to preclude the use of a separate opinion writing or review section to sift and analyze the record for the agency members or to write agency decisions, although conceivably they could write those portions of the agency's decision that relate to questions of law. On the federal level, opinion writing and the use of opinion writers is a well developed art. Many federal agencies have, under various names, an opinion writing division. This practice is also used to a considerable extent by some state administrative agencies.

Dean Landis, ${ }^{78}$ among others, objects to the fact that opinions in administrative adjudications are frequently written by persons other than the members of the agency. Aside from the question of separation of functions, the principal objection to opinion writers is based on the assumption that the process of writing the opinion in itself contributes to a more informed judgment. It is argued in this area that it is commonplace for one's thinking to be substantially changed or modified when an attempt is made to rationalize conclusions and formulate ideas in the written form. Undoubtedly, there is a great deal that can be said for this viewpoint, but, in the author's opinion, it is somewhat exaggerated. Assuming, for example, that the agency is composed of more than one person, at best only one of the members is going to have the direct benefit of this intellectual exercise. But more important, if the members of the agency regard the party who assisted in writing the decision as being merely a tool to assist them and if they accept and exercise their responsibility for the decision itself, all of the members of the agency by reviewing, supervising, and instructing the opinion writer or writers will experience much of the same intellectual process. In the last analysis, the extent to which this intellectual activity is experienced and beneficial will depend upon the personnel involved. Utilization of an opinion writing division permits much of the mechanical burden of preparing a written opinion to be assumed by others in routine cases and will permit agencies in some of their more complex cases to assign one of their members to write the opinion. ${ }^{79}$ The alternative for an agency with a large case load is either to increase its backlog or to give less consideration to the merits of the case and more to the process of writing the opinion or, as in the case of the National Labor Relations Board which is subject to compara-

\footnotetext{
${ }^{78}$ LANDIS, supra note 15 , at 19-20, 39, 47.

7 The Securities and Exchange Commission, apparently sensitive to the criticism of Landis and others, has very commendably commenced following this practice.
} 
ble restrictions, ${ }^{80}$ to have in effect several separate opinion writing divisions (personal assistants), one for each agency member.

(3)-(4) The revelation of the Harris Special Subcommittee on Legislative Oversight, ${ }^{81}$ relating to ex parte contacts between agency members and the regulated with reference to improper attempts to influence decisions, has given rise to a number of proposals. Although general legislation has not been adopted by Congress in this area, the Securities and Exchange Commission has recently announced a statement of policy ${ }^{82}$ which adopts the recommendations of the Administrative Conference so as to preclude ex parte communications with respect to "on-the-record" proceedings as between persons outside the Commission and "decisional" employees ${ }^{83}$ of the Commission.

The revised Model Act precludes the decisional employees of the agency from communicating ex parte with any person outside of the agency representing a party to the proceeding as to any issue of fact or law. ${ }^{84}$ No one denies that improper influence, like sin, is to be combated on all fronts, and if the Model Act provision went no further, it would be a salutary one. However, as to issues of fact, the decisional employees are also precluded from consulting ex parte with members of the staff except that agency members may consult with other agency members and with their personal assistants. ${ }^{85}$ The official comment to this section refers to "litigious" facts, and it is not clear whether "facts" are merely evidentiary facts. If such is the case,

${ }^{80}$ The Taft-Hartley Act precludes the board from employing attorneys for the purpose of reviewing transcripts or preparing opinions except such functions may be performed by legal assistants assigned to iudividual board members. 61 Stat. 199.40 (1947), 29 U.S.C. \$154 (a) (1958).

81 Hearings on Investigation of Regulatory Commissions and Agencies Before $a$ Subcommittee of the House Committee on Interstate and Foreign Commerce, 85th Cong., 2d Sess. (1958); 86th Cong., 1st Sess. (1959).

${ }^{82}$ Securities Act Release No. 4600 (April 26, 1963), CCH FED. SEc. L. REP. I 76,192. The Carroll committee recommended the enactment of a statute containing both criminal and civil sanctions prohibiting improper ex parte communication. See Subcommittee on Admiuistrative Practice and Procedure of the Senate Comm. on the Judiciary, supra note 12 , at 4 .

${ }^{83}$ Decisional employees are defined so as to include Commission members, the hearing officer assigned to the case, members of the staff of the Office of Opinion Writing and legal and executive assistants to Commission members. Securities Act Release No. 4600 , supra note 82 .

8. Revised Model Act $\$ 13$.

${ }^{85} \mathrm{Ibid}$. The agency may consult with persons both iuside and outside of the agency under this provision other than a person represeuting one of the parties as to questions of law. Accordingly, the agency is free to consult its own staff and also personnel of other ageucies as to questions of law. 
the main impact of the provision would be to preclude or restrict the use of an opinion writing division.

However, on the assumption that "facts" also include, or that the Act may be construed so as to include, ultimate facts and legislative facts, agencies would be precluded from utilizing the expertise of their staffs in reaching policy determinations implicit in much of administrative adjudication. The Act does recognize the right of the agency to utilize its "experience, technical competence, and specialized knowledge . . . in the evaluation of the evidence."86 One of the principal advantages of the institutional approach is that agency members are not limited by their own technical and specialized knowledge but have available a staff of experts for consultation. Frank recognition is needed of the fact that any decisionmaker, whether judicial or administrative, brings to each decision the totality of his knowledge. Agencies should not be precluded from utilizing their staffs for the purpose of resolving and formulating policy incident to adjudication even though factual assumptions, determinations, and predictions are, as is often the case, implicit in policy formulation.

A related provision of the revised Model Act ${ }^{87}$ requires with respect to adjudication that the record include "all staff memoranda or data submitted to the hearing officer or members of the agency in connection with their consideration of the case." The extent to which staff memoranda can be considered at all by the agency on matters other than questions of law depends upon the appropriate construction of the limitations on staff consultations referred to immediately above. The Act is not clear at what point such staff memoranda become a part of the record, and if, as apparently may be the case, ${ }^{88}$ they do not become part of the record until after the decision is rendered, their significance will be limited primarily to petitions for reconsideration and to judicial review. The inclusion of such staff memoranda in the record will give rise to a myriad of false issues and misdirected argument-that is, argument against the memoranda and data rather than against the agency's decision.

\footnotetext{
${ }^{80}$ Revised Model Act $\S 10$ (4).

${ }^{87}$ Id. $\$ 9$ (e) (7).

${ }^{88}$ This appears to follow from the fact that the official comment to $\$ 9$ sug gests that it might be desirable to go further than the proposed provision and require that staff memoranda be submitted for the record in time to permit adverse parties to offer evidence in reply. If staff memoranda are officially noticed, the parties must be given an opportunity to rebut to the same extent as other matters officially noticed. See supra note 66 .
} 
In addition, it will impose such administrative inconvenience from the standpoint of determining the memoranda and data to be considered by the agency that, agencies are likely to avoid all non-record consultations and considerations. It will also seriously impair the liberal exchange of ideas as between agencies and their staff members which in many instances should be, if to be freely given, on a confidential basis.

One of the proponents of the ABA proposals ${ }^{80}$ concedes that the agency in the decision making process should be able to "use its expert knowledge and experience in evaluating and drawing conclusions from the evidence that is in the record." 00 If one concedes this much and views the agency's staff of experts as merely part of the agency itself, as they appropriately are, then requiring the agency decision as to adjudicative facts to be based exclusively on the record ${ }^{91}$ should be sufficient for the purpose of drawing the line in this area. Some will object that drawing the line here does not give a party access to everything that has influenced the decision making process. However, if the process of consultation with the staff is viewed merely as an enlargement of the experience, skill and judgment that the deciding officer brings to his judgment making task, it is clear that ordinarily the parties, whether the proceeding be judicial or administrative, would have little opportunity to examine the decision making process to the extent contemplated by the revised Model Act. As an ideal, it might be desirable for any decision maker to explain and rationalize completely his decision setting forth everything extraneous to the record he may have remotely considered beyond what is reflected by the written opinion (including, for example, the elementary accounting text he relied upon in order to distinguish between a debit and credit); however, tradition and expediency necessitate that parties be limited in this regard by the somewhat inadequate opportunities available in connection with a petition for rehearing.

so The ABA proposal in this area is not identical to the Model Act provision in that although it restricts ex parte consultations in a similar manner, it does permit employees who have not participated in the investigation or the proceeding and who are not engaged in other prosecutory functions for the agency to be consulted "in analyzing and appraising the record for decision." Proposed Code of Federal Administrative Procedure $\$ 1005$ (c).

${ }^{\circ}$ Benjamin, supra note 45 , at 230.

'1 Section $9(\mathrm{~g})$ of the revised Model Act would accomplish this purpose. See text of article at note 72 supra. This is not, of course, where Mr. Benjamin would draw the line. Ibid. 
The Kentucky proposed act would utilize disclosure of staff memoranda and data as a discovery device, requiring, except to the extent the material is protected as privileged or confidential, that notice of the existence of (with opportunity to examine) pertinent staff memoranda and data be made part of the notice initiating the proceeding. ${ }^{92}$ To the extent this would make available to the respondents a list of the agency's prospective witnesses and a summary of their probable testimony, the author would endorse the proposal, particularly in the absence of other discovery procedures..$^{93}$ Presumably, such matters as strategy to be pursued and policies to be advanced in the proceeding would be protected as privileged or confidential.

\section{F. Separation of Functions}

The ironic facet of the revised Model Act is the fact that it does not assure effective separation of functions. The draftsmen apparently assumed that by cutting off substantially all consultation with the staff, separation of functions would be achieved. However, nothing in the Model Act as revised precludes one who has participated in the investigation, preparation or presentation of the agency's case from also acting as a hearing officer or deciding officer, and, to the extent agency members are permitted to consult with staff members, nothing precludes consultation with staff members who have participated in the investigation, preparation and presentation of the agency's case.

Yet the really objectionable feature of the institutional decision arises out of the possible failure to separate functions. The problem essentially is to avoid contaminating the decision making function by the prosecuting function. It is obvious that the prosecutor does not make a good judge in his own case. There are many choices in this area, but the basic choices are among (1) complete separation, (2) internal separation, and (3) no separation. Although the third choice appears to be practiced by some administrative agencies, it is doubtful whether anyone would attempt to make a case for this alternative except possibly on the basis that in view of limited staff and budget, it may be unavoidable for some agencies. A case can be made for complete separation, and there are various proposals on the federal level to accomplish complete separation within certain agencies. In certain areas complete separation substantially exists in

\footnotetext{
02 See text of article at note 61 supra.

${ }^{0 B}$ See text of article at note 62 supra.
} 
the National Labor Relations Board.94 However, complete separation is a radical solution in the sense that it would require very basic structural changes in all administrative agencies and would involve the type of controversial question that would probably make reform in this area unattainable because of lack of agreement. Further, complete separation denies to administrative "judges" any utilization of a staff, separates policy formulation through adjudication from policy formulation through rule making, and is likely to delay unnecessarily the development of standards. ${ }^{25}$ The need for complete separation has yet to be established. ${ }^{.8}$ Internal separation can and should be achieved, as it has to a large extent on the federal level, by precluding those members of the agency staff who have engaged in or are directly responsible for the investigation, preparation or presentation of the agency's case from participating in any aspect of the hearing or decision making process, including the writing of opinions. ${ }^{97}$ Provision should be made to permit agencies with small staffs to borrow employees, perhaps from the office of the state attorney general, to investigate, prepare and present cases in order to be able to comply with the separation of functions requirement.

\section{VII}

\section{Rule Making}

Our faith in the efficacy of hearings has probably caused us to extend hearing requirements to situations involving fundamentally policy questions better resolved by reports, discussions, conferences, and arguments rather than a trial type hearing which is best adapted

\footnotetext{
9s Separation is achieved by the National Labor Relations Board in "unfair labor practice" cases (but not representation cases) by making the Board's General Counsel solely responsible for investigation, initiation and prosecution of unfair labor practice cases. 6I Stat. 139 (1947), 29 U.S.C. \$ 141 (1958). The ABA proposals would establish in the judicial branch specialized courts (or divisions of a specialized court) to which would be transferred certain adjudicatory functions of the Federal Trade Commission and other trade practice cases and adjudicatory functions of the National Labor Re. lations Board and such other adjudicatory functions as Congress might from time to time determine. See Benjamin, supra note 45, at '219-23.

${ }^{\text {os }}$ Although there is some dissatisfaction with development of policy and standards by agencies under existing procedures, divorcing the responsibility for formulation of policy from the adjudicators is unlikely to contribute to the evolution of policy. See Friendly, The Federal Administrative Agencies-The NeEd for BetTer Definition of STANDARDS (1962).

${ }^{\circ 0}$ While directed to the Proposed Code of Federal Administrative Procedure, the Carroll committee remarks, supra note 28, support this conclusion.

${ }^{97}$ APA $\$ 5(c)$. However, these provisions should be extended to all contested cases as that term is defined by $\$ 1(2)$ of the revised Model Art.
} 
to resolving disputed questions of adjudicative facts. Procedures appropriate for the adoption of rules and regulations ordinarily differ from those appropriate to adjudication. If the problem under consideration, for example, is a regulation requiring certain safety devices on commercial trucks, opportunity for the interested parties to effectively present their viewpoint is what is required, and this generally can be accomplished without the trappings of a judicial type trial. Presently among some state agencies persons affected by rules and regulations having the effect of law often have an inadequate, if any, opportunity to participate in the rule making process, and there often is no system available either for the giving of notice of proposed rules or the publication and systematic indexing and codification of rules. The revised Model Act ${ }^{99}$ prescribes a procedure requiring 30 days notice to interested persons by mailing and publication of the proposed rule and requiring that interested persons be afforded an opportunity to present their viewpoints (by submitting comments and in some instances in a public type hearing). It also provides for the compilation, indexing and publication of rules and for keeping the published rules current. The Model Act rule making requirements are similar but not identical to procedures followed by federal agencies in rule making, and to the extent these requirements are adopted, they will represent a major contribution to administrative law in many states.

However, it should be noted that the revised Model Act goes beyond the Federal Administrative Procedure Act by requiring notice prior to the promulgation of "interpretative rules and general statements of policy."100 In the author's judgment, since such interpretative rulings and statements of policy do not have the force and effect of law and do not control interpretation, the revised Model Act provision imposes an unnecessary and unreasonable burden on the day-to-day agency determination of policy and interpretation. If the proposed provision extends to informal staff interpretations, it will not only be inconvenient but impossible to comply with and will destroy much of the administrative process as a living, vital, flexible means of accomplishing informal adjustments. ${ }^{101}$

\footnotetext{
${ }^{88}$ For an excellent discussion of this general problem, see Gellhorn, Administrative Procedure Reform: Hardy Perennial, 48 A.B.A.J. 243 (1962).

${ }^{\circ}$ Revised Model Act $\$ \$ 3-5$.

${ }^{200}$ Official comment to revised Model Act $\$ 3$. This is accomplished by defining "rule" in $\S(7)$ so as to include agency statements of general applicability which interpret or prescribe policy.

${ }^{201}$ The construction problem here involves determining when a statement is an
} 


\section{VIII}

\section{JUDICIAL REVIEW}

A number of problems relating to judicial review of administrative action have given rise to considerable controversy on the federal level, but they have not as yet been serious problems in many states. These include problems relating to primary jurisdiction, exhaustion of administrative remedies, and standing to challenge administrative action. ${ }^{102}$ In particular, states have generally been liberal in permitting any person with a significant interest in fact to challenge administrative action. The principal objective in drafting legislation should be to avoid statutory language that might restrict this liberal attitude; the Model Act provision could be clarified slightly in this respect. ${ }^{103}$

There are a number of problems relating to judicial review that undoubtedly will continue to reach and trouble state courts. These problems are discussed below and include the following: What administrative action is reviewable? What is the proper procedure for obtaining review? What are the mechanics of review? Upon what is the review based? What is the scope of review? What are the remedies available upon review?

\section{A. What Administrative Action Is Reviewable?}

Many statutes relating to administrative agencies and action expressly provide that specified types of administrative decisions are subject to judicial review. Generally, these review provisions relate to administrative adjudication (contested cases), infrequently to rule making, and occasionally to executive action. However, a number of statutes in some states relating to agencies with powers of adjudication do not include review provisions. On the federal level there appears to be a reasonably well developed doctrine that unless a statute affirmatively precludes judicial review, there is a common law right of judicial review of administrative action. ${ }^{104}$ The

\footnotetext{
"agency statement" and when it is of "general applicability." See note 100 supra. For the extremely important role played by informal adjustments in the administrative process, see generally Worl, administrative Law-The Informial Process (1962).

${ }^{102}$ In the area of standing in particular, the United States Supreme Court has unnecessarily made it a "complicated specialty of federal jurisdiction." United States ex rel. Chapman v. FPC, 345 U.S. 153, 156 (1953). See also DAvis, op. cit. supra note 62 , at $\$ 22.04$.

${ }^{103}$ Section 15 (a) of the revised Model Act might be improved in this respect by referring to one who is adversely affected in fact or aggrieved rather than merely to one who is aggrieved as being entitled to judicial review.

104 DAvis, op. cit. supra note 62 , at $\$ 28.07$.
} 
decisions on the state level are inconclusive. ${ }^{105}$ The Model Act as revised expressly provides that final decisions in all contested cases are reviewable by the courts ${ }^{106}$ and that the validity of all administrative rules and regulations may be determined in an action for a declaratory judgment. ${ }^{107}$ The revised Model Act contains no provision for reviewing executive action, that is, administrative action that can be classified neither as adjudication nor rule making. Yet this is an area in which judicial review may be badly needed since there are typically no procedural safeguards within the agency to prevent arbitrary action. The difficult problem in this area is distinguishing between action in which the executive's discretion is to be absolute (e.g., pardon and parole and commutation of sentences) and action in which the executive exercises discretion which can be reviewed for abuse. The author would suggest a provision to the effect that all administrative action is reviewable unless such review is precluded by "law."108 The reference to "law" as distinguished from statute is to preclude review in those areas in which traditionally the executive has had absolute discretion, including the discretion to be arbitrary.

\section{B. What Is the Proper Procedure for Obtaining Review?}

The appropriate procedure with respect to judicial review of administrative action is sometimes prescribed by statute particularly with respect to administrative adjudication. In the absence of statute there are a number of possibilities, and the multiplicity of possible proceedings on the state level has all too often resulted in judicial roulette-select the wrong proceeding and you are out of court. ${ }^{109}$ On the federal level, the injunction and declaratory judgment have frequently served as a utility remedy in those instances in which the statute prescribes no specific procedure. ${ }^{110}$ However, the effective use of the injunction as a remedy is somewhat limited by the sovereign immunity doctrine. ${ }^{111}$ The liberal allowance of mandamus sometimes effectively provides for both review of the area characterized as executive action and for affirmative relief where needed.112

\footnotetext{
${ }^{108}$ See cases cited in Note, 16 WYo. L.J. $308 \mathrm{nn} .3,4$ (1962).

100 Revised Model Act $\S 15$.

${ }^{107}$ Id. $\$ 7$.

${ }^{108}$ Cf. Chicago \& So. Air Lines v. Waterman S.S. Corp., 333 U.S. 103 (1948).

${ }^{100}$ DAvis, op. cit. supra note 62 , at $\$ 24.06$.

$110 \mathrm{Id}$. at $\$ 23.04$

${ }^{111} I d$. at $\$ 27.04$.

119 See, e.g., Board of County Comm'rs v. State, 369 P.2d 537 (Wyo. 1962).
} 
However, there is again a real danger in the multiple system of procedures for review that the wrong proceeding may be chosen. Professor Davis argues for a single proceeding to review administrative action and the abolition of all other proceedings. ${ }^{113}$ Constitutional limitations ${ }^{114}$ may preclude doing so in some states; hopefully, making it clear that the proposed proceeding, although supplemental to other remedies, is always available, may get the job done. The Model Act provides one procedure for contested cases and another procedure for reviewing rules.115 The author would suggest (following Professor Davis) a single procedure (perhaps styled as a petition for review) for the review of all reviewable administrative action. Consideration should also be given to providing that jurisdiction in all appeals from administrative action be placed, as would be the case under the Kentucky proposed act, ${ }^{116}$ in a single designated district court.

\section{What Are the Mechanics of Review?}

Many statutes and court rules specifically prescribe the time periods, papers, etc., governing appeals from administrative agencies to the courts. The Model Act prescribes the mechanics for review in contested cases, ${ }^{117}$ and these provisions could be extended with appropriate adaption to all judicial review of administrative action. Since the Model Act is tailored to the precise situation of review of administrative action, it may be better adapted to this purpose than scattered statutory provisions and will in any event prescribe needed uniformity in this area. Consideration should be given to clarifying the issues by following the Wisconsin example ${ }^{118}$ which requires that the petition for review set forth the grounds upon which relief is being sought.

\section{Upon What Is the Review Based?}

Some state statutes expressly provide that review is to be based exclusively upon the record developed by the administrative agency. However, to the extent de novo statutes are given effect, the adminis-

\footnotetext{
${ }^{113}$ Davis, op. cit. supra note 62 , at $\$ 24.06$.

114 Some state constitutions expressly purport to preserve all or some of the extraordinary remedies.

115 See text of article at notes 106-07 supra.

116 KentUCKy Legislative Research CoMm"N, supra note 3, at 89.

127 Revised Model Act $\$ \S 15$ (b)- (d) .

118 WIs. STAT. $\$ 227.16$ (1961). A similar recommendation has been made by the Administrative Conference of the United States.
} 
trative record presumably can be supplemented by testimony taken by the court. ${ }^{110}$ The Model Act ${ }^{120}$ provides in contested cases for review based upon the record developed before the agency, although the court may order the agency (emphasis supplied) to take additional evidence if, upon application of a party, it is shown that additional evidence is material and that there were good reasons for failure to present it to the agency. The Model Act ${ }^{121}$ also permits the court to take evidence on any alleged irregularity in proceedings before the agency not shown by the record. The Model Act provisions will clarify the law in jurisdictions which permit the taking of supplemental testimony before the court. To permit such supplemental testimony is to encourage poorly developed administrative records. Since it is the judgment of the agency that is being exercised, that judgment should be evaluated on the basis of the record before the agency, and the parties should be evaluated on the same basis.

Undoubtedly, some administrative agencies in the past have failed to develop an appropriate record in contested cases and may not even have had the subpoena power sometimes necessary for this purpose. This encourages courts to permit the administrative record to be supplemented. One of the advantages to a Model Act approach rather than an ad hoc approach to problems arising in the administrative law area is the fact that it permits a comprehensive and correlated approach to related problems. If the recommendations made earlier in this article are adopted, the parties will have the techniques available to both develop and preserve an appropriate record, and the agency will have rendered a written decision setting forth findings of fact and conclusions of law. However, again it should be noted that this discussion relates to contested cases (adjudication) and not to other types of administrative action. It is inappropriate in a contested case to engage in the presumption of official regularity; decisions required by statute to be made after a hearing should be supported by the administrative record. On the other hand, in the area characterized as executive action, there will be no record in the ordinary sense of that term and the record will have to be developed by the court. It is also probably appropriate

\footnotetext{
${ }^{110}$ This appears to be preserved by $\$ 15$ (a) of the revised Model Act which provides that the judicial review provisions do not limit utilization of trial de novo as provided by law.

${ }^{130}$ Revised Model Act $\$ 15$ (e).

121 Id. § 15 (f).
} 
in this area to engage in the presumption of official regularity and to require the party challenging the administrative action to carry the burden of showing an abuse of discretion.

\section{E. What Is the Scope of Judicial Review?}

The problem in this area has been to reconcile the viewpoints expressed in the quotations discussed below.

Justice Frankfurter, in sustaining a grain rate structure established by the Interstate Commerce Commission, stated: "We [the Court] certainly have neither technical competence nor legal authority to pronounce upon the wisdom of the course taken by the Commissioner." 122

Justice Douglas, in a dissenting opinion, has eloquently stated the case for judicial review, not in a civil liberties case, but in a government contract case:123 "Law has reached its finest moment when it has freed man from the unlimited discretion of some ruler, some civil or military official, some bureaucrat. Where discretion is absolute, man has always suffered ...."

On the federal level, scope-of-review criteria may be verbalized in general terms. ${ }^{124}$ The courts do not substitute judgment on questions of fact, mixed questions of fact and law, or on questions of policy. On questions of fact they apply the so-called substantial evidence rule, and on questions of mixed fact and law usually apply the rational basis test. In the area of questions of law as such, the courts are free to substitute judgment. In terms of mixed questions of fact and law, i.e., situations involving the application of a broad statutory standard to a particular set of facts, courts sometimes substitute judgment in areas in which they regard themselves as being especially competent.

On the state level, courts have varied in the degree of deference paid to administrative decisions. In the area of mixed questions and discretion, state courts are likely to talk about arbitrary and capricious action and abuse of discretion, but it is believed that this adds up to the rational basis test: that is, if there is any reasonable basis for the administrative decision on a mixed question of fact and law or question of discretion, the administrator will be sustained.

\footnotetext{
122 Board of Trade v. United States, 314 U.S. 534, 548 (1942).

${ }^{123}$ United States v. Wunderlich, 342 U.S. 98, 101 (1951).

124 See Davis, op. cit. supra note 62 , at $\$ 29.11$. Professor Davis undoubtedly would regard analysis of Supreme Court holdings in this area as being much more complex than reflected by this discussion.
} 
The Model Act quite properly, as is now required under the APA ${ }^{125}$ on the federal level, requires reviewing courts on questions of fact to base their review of administrative decisions on "the whole record."128 The Model Act also in large part adopts the criteria outlined above as to scope of review except, as revised, it provides for a "clearly erroneous" test as distinguished from a substantial evidence test with respect to questions of fact. ${ }^{127}$ Although the difference in formula can only amount to a difference in degree, it is apparent that under the clearly erroneous test the court has somewhat more authority (without the right to substitute judgment) to reverse a decision of an administrative agency on a factual question. The author would favor this departure, for it tends to offset whatever shortcomings may exist with respect to any system of internal separation and to strike a better balance between the respective functions of the agencies and the courts. Section 15 (a) of the revised Model Act preserves de novo reviews where provided for by statute; consideration should be given to completely eliminating de novo review, particularly in those jurisdictions in which the courts have construed away de novo provisions on constitutional or other grounds. ${ }^{128}$

\section{F. What Are the Remedies Available Upon Review?}

The Model Act ${ }^{129}$ appropriately precludes the reviewing court from substituting its judgment for that of the agency as to the weight of the evidence or on questions of policy. Accordingly, as to such issues courts should ordinarily either affirm or remand the administrative decision in a contested case. ${ }^{130}$ Obviously in the area of rule making the most a court can do is to affirm or deny the validity of a rule; the court cannot adopt rules for the agency. However, with respect to contested cases and executive action, it may be appropriate in certain instances for the court to reverse or modify the administrative agency and to finally dispose of the case, provided such disposition does not require the court to exercise a discretion

\footnotetext{
${ }^{125}$ APA $\$ 10$ (e). See also Universal Camera Corp. v. NLRB, 340 U.S. 474 (1951). ${ }^{128}$ Revised Model Act $\$ 15$ (g) (2).

127 Ibid. The Model Act frames the rational basis test in terms of arbitrary or capricious action or involving an abuse of discretion and, as revised, $\$ 15(\mathrm{~g})$ adds as a basis for reversal "clearly unwarranted exercise of discretion."

${ }^{128}$ The revised Model Act provisions relating to de novo judicial review are found at $\$ 15$ (a). See DAvis, op. cit. supra note 62 , at $\$ 29.10$ for state decisions invalidating de novo review provisions relating to administrative adjudication.

220 Revised Model Act $\$ 15(\mathrm{~g})$.

${ }^{230}$ Schaffer Transp. Co. v. United States, 355 U.S. 83 (1957).
} 
vested in the agency. The Model Act ${ }^{131}$ as revised specifically permits courts to grant such relief upon review in contested cases, but it fails to expressly authorize affirmative relief against an agency in those situations in which such relief may be appropriate.

\section{IX}

\section{CoNCLUSION}

The Model Act can serve as a basis for administrative reform on the state level. However, as most recently revised, in many areas it represents a retrogression. The revised Act unduly regulates the work habits of the agency, unnecessarily formalizes their procedures, precludes the agency from utilizing its staff to full advantage, and fails to appropriately separate functions. It will, at the very best, contribute to additional agency backlogs and, at the very worst, will preclude agencies from carrying out their regulatory functions. To adopt language of a Carroll committee report, ${ }^{132}$ the revisions to the Model Act evidence "far too much confusion between fair procedures and formal procedures."

\footnotetext{
${ }^{181}$ Section $15(\mathrm{~g})$ of the revised Act permits the courts to affirm, reverse, modify or remand the case for further proceedings.

${ }^{132}$ See Carroll committee, supra note 12, at 2. The Carroll committec criticisms relate primarily to the ABA proposals; however, there is sufficient similarity betwcen the revised Model Act and the Proposed Code of Federal Administrative Procedures to warrant reference to that committee's comments. The Carroll committce, id. at 10, recommended against the enactment of a general revision of the Administrative Procedure Act specifically referring in this regard to the Proposed Code of Administrative Procedure. The committee in effect concluded that the case for the Proposed Code has not been established. The committee said: "On the other hand, the subcommittee has received comments from 33 agencies which almost unanimously expressed the fear that the proposed code would increase their difficulties in disposing of the business before them, with little or no increase in fairness of proccdure or quality of decision. The study and thoughtfulness by the 32 agencies that came to the conclusion shared by this subcommittee reinforces that conclusion, namely, that drastic tinkering with the Administrative Procedure Act is undesirable at this time." Ibid. Senator Dirksen of Illinois filed a statement of his individual views and apparently did not join in the subcommittee's statement.
} 